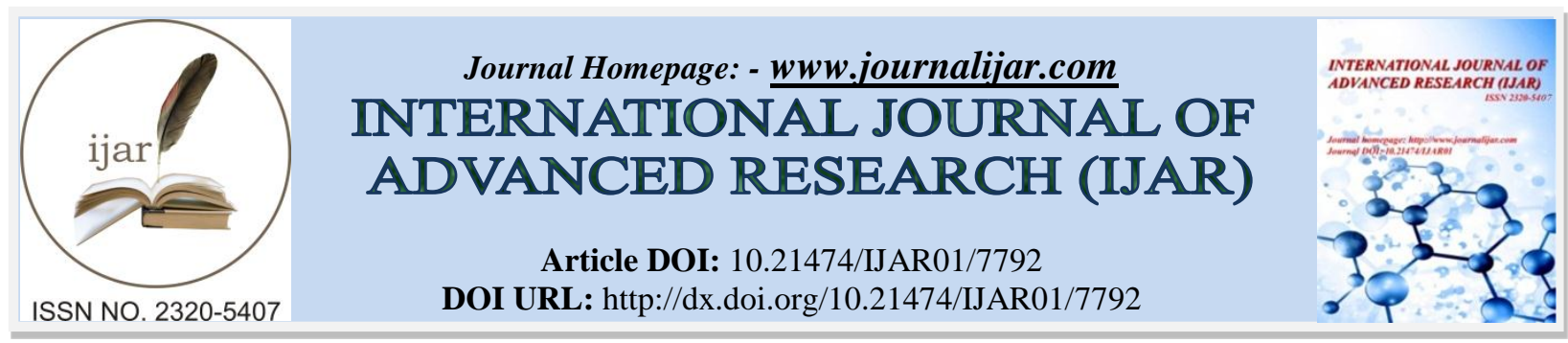

RESEARCH ARTICLE

\title{
THE IMPACT OF MICROTEACHING METHOD ON PROFESSIONAL KNOWLEDGE AND SKILLS OF ELEMENTARY MATHEMATICS TEACHER CANDIDATES
}

\author{
Alper Çiltaş and Rabia Nur Öndeş
}

\section{Manuscript Info}

Manuscript History

Received: 2 August 2018

Final Accepted: 4 September 2018

Published: October 2018

Keywords:

Micro-Teaching, Elementary

Mathematics Teacher Candidates

\begin{abstract}
It was aimed to investigate the development of pre-service elementary mathematics teachers' teaching skills through microteaching connecting theory to practice. So, 12 selected volunteers from the sample consisting 74 forth-year participants have recorded their teaching videos in training schools. These videos were watched in the course lasting 14 weeks and feeedbacks were given by their peers according to assessment forms given. After this procedure was repeated, the first and second microteachings were compared. According to findings, it was shown that they made a positive progress. Also, they expressed their views in terms of microteaching contributions to the lesson plan process, its strong sides and weak sides. Thus, it can be suggested that microteaching should be used in teacher training courses more frequently to enable them to make practice more, and hence improve their teaching skills.
\end{abstract}

Copy Right, IJAR, 2018,. All rights reserved.

\section{Introduction:-}

Individuals are expected to keep up with the rapidly changing world. In this sense, gaining knowledge and skills have a huge effect on becoming a qualitative person. Using their own knowledge and skills and applying them to daily life problems, especially in their own professional fields indicate their quality. So, micro-teaching method connecting theoretical knowledge to practice have an important role in this context since it allows individuals to trial and exercise systematically in a safe artificial or laboratory environment (Brent, Wheatley, \& Thomson, 2015; Fernandez, 2010). Microteaching generally includes planning, preparation, implementation, feedback and reimplementation stages (Belt, 1967) and it can be used in so many different disciplines from sport coaching to medical education (Ralph, 2014). Thus, it can be considered as a simulation method used by actors, lawyers, engineers, musicians, architects, doctors, athletes and so on before showing their performance as a whole (Çakır, 2000). For instance, micro-teaching is used in mock trials that lawyers act like judge, witness or lawyer in order to prepare lawyers for real case.

Pre- service teachers are expected to learn teaching in university courses and make practice in the courses like school experience and practice teaching as an intern. However, they need to put different teaching methods into practice and gain experience about instructional materials and classroom management before teaching in real environment. As a result, minicourses or microteaching classes as a campus clinical experiment that enable student teachers to act as a teacher in artificial and safe environment have been using in universities (Belt, 1967; Brent, et al., 2015) since 1976 when Standford was begun to use it to train teachers (Borg, Kallenbach, Morris, \& Friebel, 1969) Specifically, this method used for reduction of complexity in the learning and teaching process is an essential tool to prepare pre-service teachers for future careers (Brent, et al., 2015). In this context, pre-service teachers play 
the roles of teacher and students when teaching a short lesson through a specific objective. They should plan their lessons (lesson plans), need to prepare themselves, teach their lessons as a teacher, and their instructors, colleges or friends should give them feedback with respect to their instructions, then they should re-plan, re-teach their lessons according to the feedbacks given (Belt, 1967). In this process, videotaped lessons and feedbacks (Belt, 1967) are two essential components of microteaching (Benton-Kupper, 2001). Recording their teachings on videotapes let them see themselves in action as well as others and replay and stop them as many times as possible if something has been missed (Belt, 1967; Benton-Kupper, 2001). Besides, observing the peers making micro teaching, analyzing their instructions and giving them feedbacks make micro-teaching more effective method because it allows them to see others' weak and strong sides and correct themselves (Atav, Kunduz, \& Seçken, 2014; Belt, 1967; Benton-Kupper, 2001; Bilen, 2015; Görgen, 2003; Ralph, 2014). Also, using a written paper, rubrics, rating scale checklists or an assessment form enable observers to be more comfortable when giving feedback to their friends (Brent, et al., 2015; Ekşi, 2012; Pauline, 1993).

According to the literature including the previous researches focusing on the effects of microteaching on student teachers views and teaching skills show that it provides the following benefits and disadvantages as shown in Table 1. Briefly, it contributes to an increase on the development of teaching/ instuructional skills (Belt, 1967; Bilen, 2015; Karadağ, \& Akkaya, 2013; Kuran, 2009) and gaining experiments (Brent, et al., 2015; Kuran, 2009) in preparetion for field experiences and the increase on the understanding of the importance of its components which are feedback, pedagogy and process stages. Besides, microteaching with many benefits as mentioned has some disadvantages like a camera excitement and an unfair peer assessment (see Table 1.). Also it has been criticized as not teaching actual pupils (Ralph, 2014), and hence expanded microteaching version enabling to teach in real classroom environments has been using in some areas (Belt, 1967; Peker, 2009).

Table 1:-Effects of micro-teaching : A synthesis of researches

\begin{tabular}{|c|c|}
\hline \multirow[t]{4}{*}{ The opportunity to } & - $\quad$ Connect theory to practice (Brent, et al., 2015; Kuran, 2009) \\
\hline & $\begin{array}{l}\text { - See strengths and weaknesses of themselves/others (Belt, 1967; Benton- } \\
\text { Kupper, 2001; Brent, et al., 2015; Gürbüzoğlu Yalmanc1, \& Aydın, 2014; } \\
\text { Ralph, 2014) }\end{array}$ \\
\hline & $\begin{array}{l}\text { - Experience of making plan and practice (Brent, et al., 2015; Borg, et al., } \\
\text { 1969; Kuran, 2009; Ralph, 2014) }\end{array}$ \\
\hline & - $\quad$ See different types of classroom situations/interactions (Belt, 1967) \\
\hline \multirow[t]{9}{*}{ Developments of } & $\begin{array}{l}\text { - Self-confidence (Belt, 1967; Bilen, 2015; Karadağ, \& Akkaya, 2013; Kuran, } \\
\text { 2009; Peker, 2009; Ralph, 2014) }\end{array}$ \\
\hline & 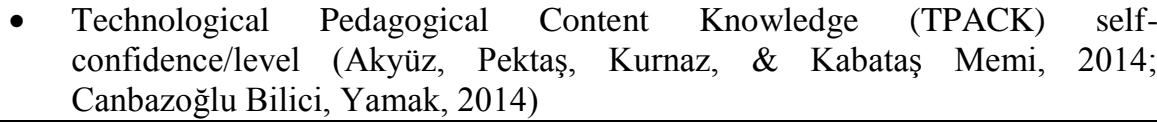 \\
\hline & $\begin{array}{l}\text { - Pedagogical Content Knowledge (PCK) level (Fernandez, 2010; Kartal, } \\
\text { Öztürk, \& Ekici, 2012) }\end{array}$ \\
\hline & $\begin{array}{l}\text { - Communication skills (Benton-Kupper, 2001; Gürbüzoğlu Yalmancı \& } \\
\text { Aydın, 2014) }\end{array}$ \\
\hline & $\begin{array}{l}\text { - Speaking skills in front of the community (Benton-Kupper, 2001; Bulut, } \\
\text { Açı, \& Çiftçi, 2016; Gürbüzoğlu Yalmancı \& Aydın, 2014) }\end{array}$ \\
\hline & $\begin{array}{l}\text { - Time management skills (Karadağ, \& Akkaya, 2013; Kuran, 2009; Peker, } \\
\text { 2009) }\end{array}$ \\
\hline & $\begin{array}{l}\text { - Classroom management skills (Fernandez, 2010; Gürbüzoğlu Yalmancı, \& } \\
\text { Aydın, 2014; Karadağ, \& Akkaya, 2013; Peker, 2009) }\end{array}$ \\
\hline & $\begin{array}{l}\text { - Probing Questioning skills \& conducting discussion behaviours (Borg, et al., } \\
\text { 2015; Fernandez, 2010; Friebel, \& Kallenbach, 1969; Kuran, 2009; Peker, } \\
\text { 2009) }\end{array}$ \\
\hline & $\begin{array}{l}\text { - Reduction in concerns about teaching (Fernandez, 2010; Görgen, 2003; } \\
\text { Gürbüzoğlu Yalmancı, \& Aydın, 2014; Peker, 2009) }\end{array}$ \\
\hline \multirow{2}{*}{$\begin{array}{l}\text { Increases on the } \\
\text { understanding of the } \\
\text { importance of }\end{array}$} & $\begin{array}{l}\text { - Planning, preparation, implementation stages (Benton-Kupper, 2001; Peker, } \\
\text { 2009; Ralph, 2014) }\end{array}$ \\
\hline & - $\quad$ Pedagogy (Ralph, 2014) \\
\hline
\end{tabular}




\begin{tabular}{llll}
\hline & $\bullet$ & Feedback (Belt, 1967; Benton-Kupper, 2001; Fernandez, 2010; Ralph, 2014) \\
\hline $\begin{array}{l}\text { Disadvantages } \\
\text { microteaching }\end{array}$ & of & $\bullet$ & $\begin{array}{l}\text { Excitement, in front of the camera or friends/students (Çakır, 2000; } \\
\text { Gürbüzoğlu Yalmanc1, \& Aydın, 2014; Karadağ, \& Akkaya, 2013) }\end{array}$ \\
\cline { 2 - 3 } & $\bullet \quad \begin{array}{l}\text { Biasness due to peer assessment (Brent, et al., 2015; Gürbüzoğlu Yalmanc1, } \\
\text { \& Aydın, 2014) }\end{array}$ \\
\hline
\end{tabular}

Traditional microteaching is most often used with small groups to train pre-service teachers and to raise their teaching qualities (Belt, 1967). In Turkey, $23 \%$ of the studies on microteaching have more than 50 participants (Güven, Kahveci, Öztürk, \& Akın, 2016) although the average classroom size exceeds about 20. Accordingly, it was observed that pre-service elementary mathematics teachers in the state university had limited teaching experience as they have been going to training schools without having the opportunity to make practice before (Ralph, 2014). So, it was aimed to use expanded microteaching in a different way that is appropriate for crowded classes, and hence to provide them with an environment that enables them to do simulations, improve their teaching skills by taking and giving feedbacks, to see minimized instruction samples and make evaluations. In this sense, the purpose of this study is to investigate the impact of micro-teaching method on the professional knowledge and skills of pre-service elementary mathematics teachers.

\section{Method:- \\ Research Design}

The study aims to investigate the development of the pre-service elementary mathematics teachers' professional knowledge and skills through microteaching and to examine their views about it. In the line with this purpose, case study from qualitative research approaches is appropriate to be preferred for this study. Since the case study covers the study of social phenomenon carried out within the boundaries of a social system (s), such as people, organizations, groups, individuals, local communities in which the phenomenon to be studied enrolls in the case's natural context. Also, it allows monitoring individuals and their developments in specific phenomena during a certain period (Swarborn, 2010).

\section{Participants}

The research was conducted with 74 elementary mathematics teacher candidates in the fourth year of the education program in a state university during the undergraduate course, entitled "Practice Teaching". The course took 14 weeks and throughout the semester 12 of the participants enrolled in this course were chosen as volunteers for recording their own microteachings in the schools where they go to as an intern.

\section{Process}

The number of the study group is more than the number of members used in standard microteaching applications and the entire lessons (40-45 minute) enable them to use more methods in the teaching experiences (Pauline, 1993), which lead us to using adopted version of this method for this study. As a procedure, the cyclical steps were followed for once. Firstly, 12 volunteer pre-service teachers prepared their lesson plans and made instruction on their training schools with actual students. Secondly, all participants watched their records in the university. The tapes were paused in some particular parts and participants' views were asked about them. Thirdly, feedbacks from peers were given to volunteers according to the observation forms provided by researchers. At this point, approximately three classmates selected randomly by researchers assessed microteaching record of one student teacher. Then, same pre-service teachers were expected to re-plan their lessons and make second microteaching by considering the given feedbacks. Finally, their second microteaching records were watched and assessed by observation forms in a same way.

\section{Data Collection Tools}

Three forms and videos were used as data collection tool and descriptive statistics were used in the analysis of the data.

1. "Micro Teaching Peer Assessment Form" accessed from Şahinkayası, includes 18 items with the points as very good (4), good (3), middle (2), weak (1), nothing (0), unrelated, and the categories of introduction to the lesson, implementation, ending/ assessment and general features. For each video, approximately three participants were selected randomly to assess their classmates' video by using the form. 
2. "Micro Teaching Evaluation Form" obtained from Karadeniz, contains 28 items with the options as very good, good, middle, weak. Also, this form was used by approximately three participants selected randomly to assess videos.

3. "Micro Teaching Self Assessment Form" was applied all participants to learn their thoughts and reflections about microteaching experiment concerning three questions ("what are the contributions of the microteaching to the process of lesson planning? what are the strong sides of the microteaching? what are the weak sides of the microteaching?").

\section{Findings:-}

In this study, the forms "Micro Teaching Self Assessment Form" and "Micro Teaching Evaluation Form" used by peers in order to assess 12 volunteer student teachers' micro teaching records were analyzed to compare the first and second micro-teaching performance averages, and the form called "Micro Teaching Self Assessment Form" given to all students was analyzed descriptively. The findings of each form were given under the three sections below.

\section{Analysis of Micro Teaching Peer Assessment Form}

Table 2 demonstrates one of the participants' average scores obtained from each item in this form to compare the first and second microteaching performances.

Table 2:-First and Second Microteaching Performances of the Participant coded by KA

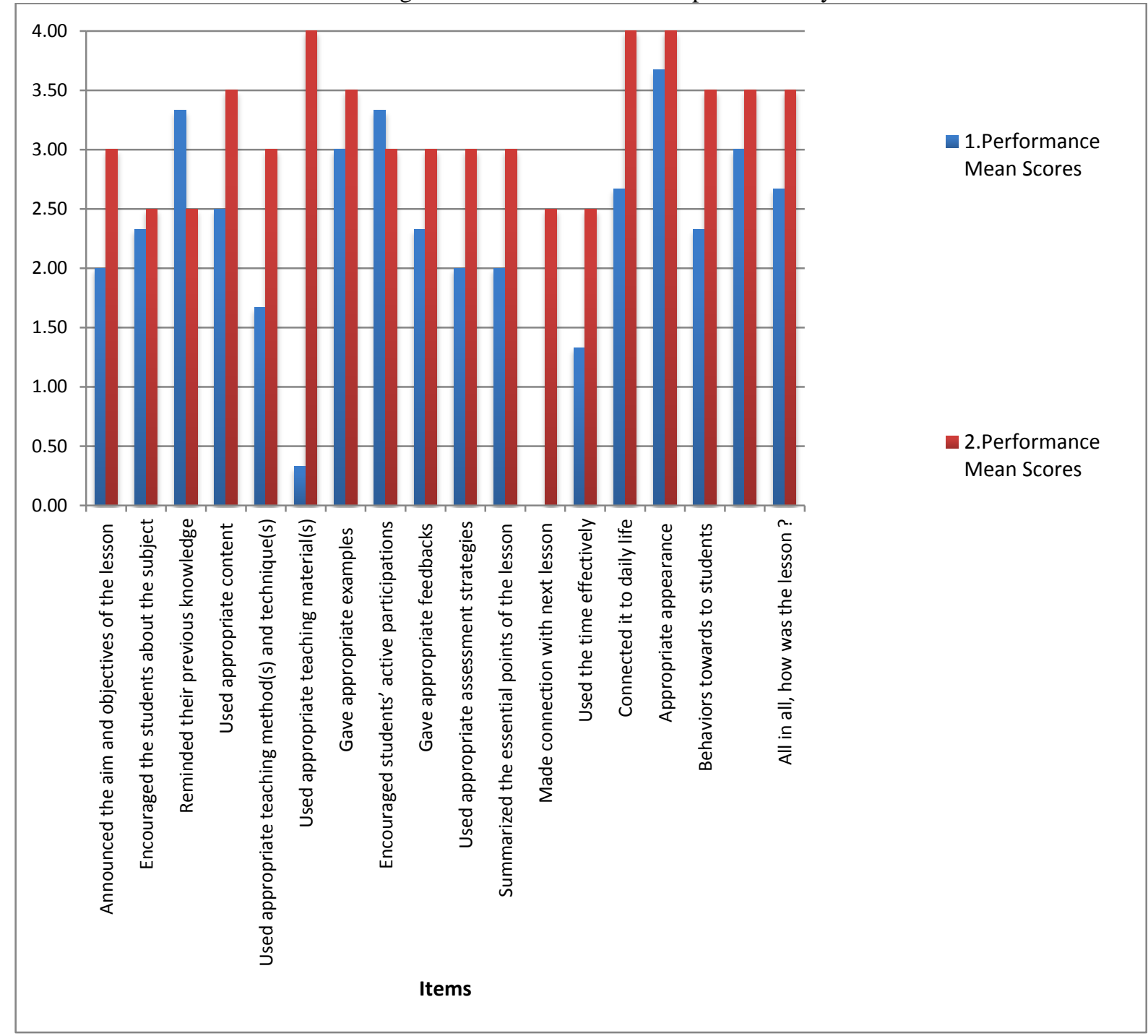


According to Table 2, the student teacher coded by KA shows an increase on most of the items of second performance in reference to first performance. For instance, KA' situation of using appropriate teaching materials has been increased from 0.33 to 4.00 point as an average in peer assessment.

Also, Table 3 shows the mean scores of all items in this form for 12 participants' first and second performances. It can be seen that their average scores increased from first to second performance with different rates.

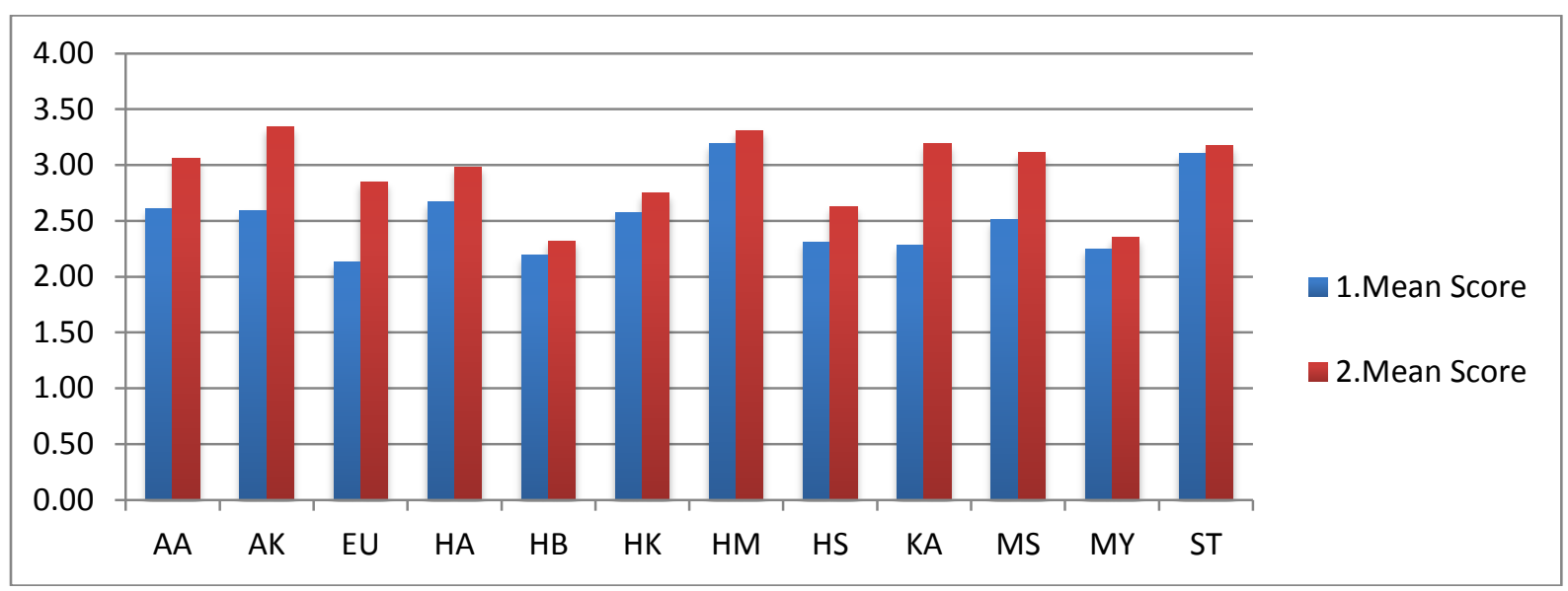

As seen in Table 3, EU having the least mean score (2.13) on the first assessment raised it to 2.85 in the second microteaching. AK get the highest score (3.34) on the second microteaching assessment when the mean value of all second scores is 2.92. Also, the biggest difference between the first and second scores belongs to KA with 0.91.

\section{Analysis of Micro Teaching Evaluation Form}

Table 4 shows the average number of ticks marked on the form items by about three observers as very good, good, middle and weak for each participant's first and second performances. According to this table, it can be seen that the number of ticks on very good and good in first performance generally are less than the number of ticks in second performance, and the number of ticks on middle and weak in first performance are generally more than the number of ticks in second performance.

Table 4:-The average number of ticks marked for each participant's first and second performances

\begin{tabular}{|c|c|c|c|c|c|c|c|c|c|}
\hline Rates & & Very & & Good & & Midc & & Wea & \\
\hline & \multicolumn{8}{|c|}{ Participants } & 2.M \\
\hline AA & & 13 & 16 & 11,7 & 9,4 & 2,7 & 2,4 & 0,4 & 0,4 \\
\hline AK & & 2 & 8,7 & 15,4 & 14,7 & 9,4 & 3,7 & 0 & 0 \\
\hline EU & & 4 & 6,4 & 13,4 & 8,7 & 7,7 & 3 & 3 & 0,7 \\
\hline HA & & 10,7 & 20,4 & 12,4 & 7 & 3 & 0,7 & 0,4 & 0 \\
\hline $\mathrm{HB}$ & & 1 & 2 & 5 & 9 & 12,7 & 5,4 & 7,7 & 5,4 \\
\hline HK & & 3 & 4,7 & 7,7 & 9 & 6,7 & 4,7 & 2 & 0 \\
\hline $\mathrm{HM}$ & & 9,5 & 13,8 & 12,5 & 11,3 & 5,5 & 2,8 & 0 & 0,3 \\
\hline HS & & 3 & 4 & 15 & 16 & 3,5 & 6 & 0 & 2 \\
\hline KA & & 3,4 & 8,4 & 11,7 & 12,4 & 8 & 6 & 2,4 & 1 \\
\hline MS & & 8 & 8 & 14,7 & 14,7 & 7,4 & 4,4 & 0 & 0 \\
\hline MY & & 4,7 & 5 & 14,7 & 14,4 & 7,4 & 7 & 0,7 & 0,7 \\
\hline ST & & 8 & 5 & 14 & 12,7 & 5,4 & 8,4 & 0,4 & 2,4 \\
\hline
\end{tabular}

For example, as seen in Figure 2 belongs to the participant coded as KA, the number of items marked as very good and good increased from 3.4 to 8.4 and from 11.7 to 12.4 respectively while the number of items marked as middle and weak decreased from 8 to 6 and from 2.4 to 1 respectively. 


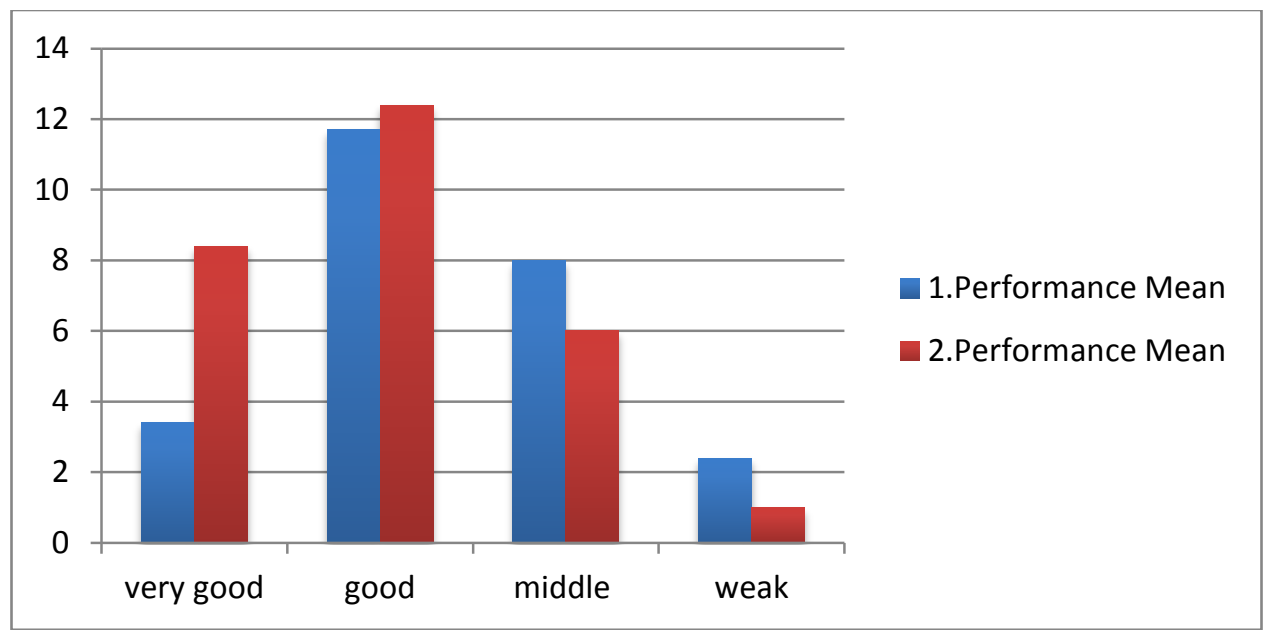

Figure 2:-The average number of ticks belongs to KA

\section{Analysis of Micro Teaching Self-Assessment Form}

Responses of all participants were analyzed under three categories as the contributions to the lesson plan process, the strong and weak sides of microteaching.

Pre-service teachers stated that micro-teaching applications enabled them to increase the knowledge and skills related to the lesson plan process by gaining experience about time management, lesson organization, selection of appropriate material or method for a lesson, building teacher-student dialogs, designing questions for student involvement in lesson and arranging the parts (starting and ending) of a lesson (see Table 5).

Table 5:-Participants' Responses about the Contributions of microteaching to the lesson plan process

Contributions to the lesson plan process

Gaining experience about

- Time arrangement

- Lesson organization

- Appropriate material/method selection

- Building teacher-student dialogs

- Designing questions for student involvement in lesson

- Arranging starting and ending parts of a lesson

Some written responses of participants were given in the below as an example for the contributions to the lesson plan process.

1. ...I saw how to use the time and how to make contact with students from the studies that my classmates did.

2. I have understood better how much useful going to the lesson with plan and program is. Similarly, I have noticed that beginning and ending the lesson effectively are significant points.

3. I think teaching method, steps of teaching a subject, communication with students, watching the teaching back, taking feedbacks from those who participate in assessment, watching their own teaching objectively and making self-evaluation are beneficial in terms of revision.

Furthermore, as strong sides of the microteaching it was asserted that it leads to the developments of criticism, observation, classroom management and time management skills. Also, it contributes to the developments of selfconfidence, setting the tone of voice and speaking speed, effective board usage and convenient language usage. In addition to them, it helps to develop the ability to select appropriate instructional material/method for lessons, to overcome concerns of making mistake and managing class, to deal with class issues and increase on the attention for not causing teacher-based misconceptions and the understanding of the importance of feedback, pedagogy and planning stage. Besides, it provides an environment for implementing the theoretical knowledge, identifying the strengths and weaknesses, observing sample student-teacher dialogs and different types of class situations (see Table $6)$. 
Table 6:-Participants' Responses about the strong sides of microteaching

\begin{tabular}{|c|c|}
\hline \multicolumn{2}{|l|}{ Strong sides of microteaching } \\
\hline Development of & $\begin{array}{l}\text { - } \text { Criticism skills } \\
\text { - } \quad \text { Self-confidence } \\
\text { - } \text { Classroom management skills } \\
\text { - Setting the tone of voice } \\
\text { - } \quad \text { Setting the speaking speed } \\
\text { - Time management skills } \\
\text { - Using the board effectively } \\
\text { - Using convenient language } \\
\text { - The ability to select appropriate instruction } \\
\text { - } \quad \text { material/method } \\
\text { - The ability to deal with class issues } \\
\text { misconceptions } \\
\text { The understanding of the importance of } \\
\text { feedback, pedagogy and planning stage before } \\
\text { lecture } \\
\text { The ability to overcome concerns of making } \\
\text { mistake and managing class }\end{array}$ \\
\hline Providing an environment for & $\begin{array}{l}\text { - } \text { Implementing the theoretical knowledge } \\
\text { - } \\
\text { - } \text { Identifying the strengths and weaknesses } \\
\text { - Observing sample teacher-student dialogs } \\
\text { Observing different types of classroom } \\
\text { situations }\end{array}$ \\
\hline
\end{tabular}

Some participants' expressions related to its strong sides were given as an example below.

1. It provides to notice the effects of personal features like attitude, behavior, gesture, facial expressions and diction on teaching.

2. I overcame my board anxiety. My self-confidence has increased.

3. It contributes to reflective thinking skills, critical thinking and peer evaluation.

4. ...It contributes to me in a positive way. It enables to see inadequalities of us or our friends or the liked sides of our friends that make microteaching.

5. Planning process of microteaching has improved my observation skill. Especially, I saw the inequalities from the outside when I watching them. I have found the opportunity to make self-criticism, classroom management and observing communications with students.

For the weak sides of the micro-teaching, it was pointed that there exists technological and technical issues like low quality of video image and limited/lack instructional materials. Also, limited time and unfair peer judgment were considered as external factors making microteaching ineffective. The concern about being criticized and anxious about speaking in front of the society and/or camera were stated as internal factors (see Table 7).

Table 7:-Participants' Responses about the weak sides of microteaching

\section{Weak sides of the microteaching}

- Technological and technical issues (low quality of video image, limited/lack instructional materials)

- $\quad$ Limited time

- Unfair peer judgment

Internal factors

- Concern about being criticized

- Anxious about speaking in front of the society and/or camera 
Some participants' expressions related to its strong sides were given as an example below.

1. They may not want to make microteaching because they are anxious about being criticized. Technological inequalities and breakdowns may be in microteaching.

2. Camera support should be given in terms of the quality picture and sound for presentations.

3. Teachers cannot apply the teaching method or technique that they use normally in their teachings due to the concern about criticism and they cannot behave in a relaxed manner when communicating with students.

4. Concern about being unable to manage the classroom.

5. Being biased or unfair person who complete the forms of the ones making microteaching are the negative sides of microteaching.

\section{Discussion \& Conclusion:-}

The present study aiming to train pre-service elementary mathematics teachers through microteaching was conducted by following the procedure including the steps of planning, teaching, feedback, re-plan, re-teaching and feedback. In this process, 12 volunteered participants were recorded during their teaching practice session in training schools, and then their videos were watched in the university and their performances were assessed with respect to the given forms. At the end, all participants' views about microteaching were taken and analyzed descriptively.

According to findings of two assessment forms used to provide structural framework for peers, it was observed that the volunteer participants made a positive progress when their first and second performances were compared. So, it can be identified that they mostly considered the given feedbacks in their second microteaching performances to improve their teachings. In this context, it can be concluded that microteaching applications should be used more than once for each pre-service elementary mathematics teachers in preparation for becoming effective teachers before sending them to training schools without giving the opportunity to practice teaching by taking feedbacks and see others weak and strong sides in different sample videos and evaluate them by using forms. Since they showed an increased performance in this study, they can improve themselves more if the chance of practicing more than twice was given to them.

On the other hand, their views were examined under three sections, which are the microteaching's contributions to lesson plan process, its strong and weak sides. Their expressions are parallel to the analysis of studies conducted in the literature related to the microteaching (see Table 1, 5, $6 \& 7$ ). As its contributions to lesson plan process, they stated that they have gained experience about time management, lesson organization, selection of appropriate material or method for a lesson, building teacher-student dialogs, designing questions for student involvement in lesson and arranging the parts (starting and ending) of a lesson. This may result from the fact that a lesson plan should be designed by considering the duration and how much time should be spend on each part, which leads to time management. Also, which materials or methods to be used in a lesson were determined in the lesson planning stage may contribute them to select appropriate ones. Since planning a lesson requires designing which order to be followed (organization), setting its parts (start-middle-end), constructing probing questions to encourage student involvement (Borg, et al., 2015; Fernandez, 2010; Friebel, \& Kallenbach, 1969; Kuran, 2009; Peker, 2009) and writing expected student answers lead them to gain experience on these categories as contributions to lesson planning (Brent, et al., 2015; Borg, et al., 1969; Kuran, 2009; Ralph, 2014).

Other question to be considered in interpreting the findings of this study is related to the strong sides of microteaching. It was stated that it leads to the developments of criticism, observation, classroom management and time management skills, self-confidence, setting the tone of voice, speaking speed, effective board usage, convenient language usage, the ability to select appropriate instructional material/method for lessons, the ability to overcome concerns of making mistake and managing class, the ability to deal with class issues, the attention for not causing teacher-based misconceptions, the understanding of the importance of feedback, pedagogy and planning stage. Besides, it provides an environment for implementing the theoretical knowledge, identifying the strengths and weaknesses, observing sample student-teacher dialogs and different types of class situations. As a result of the fact that microteaching enables them to practice their theoretical knowledge (Brent, et al., 2015; Kuran, 2009) and watch others' teachings, they may have an opportunity to observe other teachers and see their conversations in different types of class situations, and hence they can develop their observation skills. Also, watching videos and giving feedbacks that are the parts of microteaching enable them to identify their own and others' strengths and weakness during lesson (Belt, 1967; Benton-Kupper, 2001; Brent, et al., 2015; Gürbüzoğlu Yalmanc1, \& Aydın, 2014; Ralph, 
2014), which may lead them to develop criticism skills (Belt, 1967; Benton-Kupper, 2001; Fernandez, 2010; Ralph, 2014). At this point, they also may get the opportunity to see other classroom settings and dialogs (Belt, 1967). Furthermore, since they have to tell an identified subject or objective in the limited time (approximately 45 minlesson hour), they should have to use the given time effectively and help students to understand the subject. For this reason, they may express that microteaching contributes to the development of their skills of time management (Karadağ, \& Akkaya, 2013; Kuran, 2009; Peker, 2009), setting the tone of voice, setting the speaking speed, using convenient language, the attention for not causing teacher-based misconceptions, selecting appropriate instructional material/method for lessons. In addition to these, they should have to manage the class and solve the classroom problems and use the board effectively to show expressions, visualize concepts and encourage student involvement while teaching. Thus, it may not be unexpected to see in their comments that microteaching developed their classroom management skills (Fernandez, 2010; Gürbüzoğlu Yalmanc1, \& Aydın, 2014; Karadağ, \& Akkaya, 2013; Peker, 2009), the ability to deal with class issues, effective board usage skills (Benton-Kupper, 2001; Gürbüzoğlu Yalmanc1 \& Aydin, 2014). Moreover, as stated in the opinions of participants, it has a positive effect on the development of self-confidence (Belt, 1967; Bilen, 2015; Karadağ, \& Akkaya, 2013; Kuran, 2009; Peker, 2009; Ralph, 2014) and the ability to overcome concerns of making mistake, managing class (Fernandez, 2010; Görgen, 2003; Gürbüzoğlu Yalmanc1, \& Aydın, 2014; Peker, 2009), which can be the reason of making practice leading them to make less mistake and gain confidence in their fields.

In addition to strong sides, the weak sides of microteaching were identified as external factors that are technological/technical issues like low quality of video image and limited/lack instructional materials, limited time and unfair peer judgment, and internal factors which are the concern about being criticized and anxious about speaking in front of the society and/or camera (Benton-Kupper, 2001; Bulut, Açık, \& Çiftçi, 2016; Gürbüzoğlu Yalmanc1 \& Aydın, 2014). Being observed and criticized by others can cause them concern about it. Additionally, since they did not get used to speak on the camera and they cannot get back what they said here, they may feel uncomfortable (Çakır, 2000; Gürbüzoğlu Yalmancı, \& Aydın, 2014; Karadă̆, \& Akkaya, 2013) and this may affect their performances negatively. In this sense, it can be suggested that practicing more than once on the camera before lecturing can help them overcome these concerns and understanding that constructive criticisms are useful for their improvements in teaching can help them to see this process as normal. For an unfair peer judgment (Brent, et al., 2015; Gürbüzoğlu Yalmanc1, \& Aydın, 2014) mentioned as its weak aspect, structured forms were used and the average of about three peers' assessments were used in this study. However, it can be a problem that participants' rating approaches are different from each other. At this point, it can be suggested that instructor can define rating scale and give examples about different situations to standardize their grading. Also, technological/technical issues like low quality of video image and limited/lack instructional materials stated in weak sides were the limitations of this study. Because the participants shot videos through their own means and they used their own instructional materials. Therefore, it can be inferred that there is a need of mathematics laboratory (Friebel \& Kallenbach, 1969) that has different instructional materials and manipulatives which pre-service teachers are allowed to use in their training schools and a microteaching class that has video camera(s) and desks available for designing different teaching approaches and practicing them.

To sum up, the findings of the current study and literature revealed that microteaching that builds a bridge between the theory and practice is necessary for prospective teachers in their trainings for becoming teacher. Also, this study has indicated that microteaching can be carried out in crowded classrooms.

\section{Suggestions}

1. Microteaching was implemented in the last year of the education program before pre-service teachers graduated from the university. However, it could have implemented in other courses in order to provide them more time to make practice and develop themselves. So, it can be suggested that microteaching should integrated into courses including pedagogy, pedagogical content knowledge and technological pedagogical content knowledge. Also, their improvements can be observed during two years instead of one semester.

2. In this study that participants taped on video have showed better performance on the second video with respect to observation forms. Thus, it can be suggested that using microteaching and giving feedback should be used more than once for each pre-service teachers to educate them.

3. For crowded classes, students can be separated into small groups, each group can tape their teachings and randomly selected students can give feedbacks by watching them and some fundamental points can be discussed in class. 
4. The assessment forms or rubrics that focuses on content of the specific field can be used for give more productive feedbacks. So, the environment that they the discuss how to teach concepts better can be created for improve their technological pedagogical content knowledge as well as pedagogical content knowledge.

5. Mathematics laboratory can be opened in order to provide students with various instructional materials, manipulatives that they experience how to use them and micro classes including video camera(s) that enables for microteaching in safe environment can be designed.

\section{Acknowledgement:-}

The extended summary of this article was presented at 27th International Conference on Educational Sciences ICESUEBK 2018 in Antalya, Turkey.

\section{References:-}

1. Akyüz, H. İ., Pektaş, M., Kurnaz M. A., \& Kabataş Memi, E. (2014). Akıllı tahta kullanımlı mikro öğretim uygulamalarının fen bilgisi öğretmen adaylarının tbap'larına ve akıllı tahta kullanıma yönelik algılarına etkisi. Cumhuriyet International Journal of Education-CIJE, 3(1), 1-14.

2. Atav, E., Kunduz, N., \& Seçken, N. (2014). Biyoloji eğitiminde mikro öğretim uygulamalarına dair öğretmen adaylarının görüşleri. Hacettepe University Journal of Education, 29(4), 01-15.

3. Belt, W. D. (1967). Microteaching observed and critiqued by a group of trainees. Paper presented at annual meeting of the American Educational Research Association, New York.

4. Benton-Kupper, J. (2001). The microteaching experience: Student perspectives. Education, 121(4).

5. Bilen, K. (2015). Effect of micro teaching technique on teacher candidates' beliefs regarding mathematics teaching. Procedia-Social and Behavioral Sciences, 174, 609-616.

6. Borg, W. R., Kallenbach, W., Morris, M., \& Friebel, A. (1969). Videotape feedback and microteaching in a teacher training model. The Journal of Experimental Education, 37(4), 9-16.

7. Brent, R., Wheatley, E., \& Thomson, W. S. (1996). Videotaped microteaching: Bridging the gap from the university to the classroom. The Teacher Educator, 31(3), 238-247. doi: 10.1080/08878739609555115

8. Bulut, K., Açık, F., \& Çiftçi, Ö. (2016). Mikro öğretim tekniğinin türkçe öğretmen adaylarının konuşma becerilerine etkisi. Ana Dili Eğitimi Dergisi, 4(1), 134-150.

9. Canbazoğlu Bilici, S. ve Yamak, H. (2014). Teknolojik pedagojik alan bilgisi temelli bir araştırmada öğretmen adaylarinin mikroöğretim hakkindaki görüşleri. Mehmet Akif Ersoy Üniversitesi Eğitim Fakültesi Dergisi, 32 (1).

10. Çakır, Ö. S. (2000). Öğretmen yetiştirmede teoriyi pratiğe bağlayan mikro-öğretimin Türkiye'deki üç üniversitede durumu. Hacettepe Üniversitesi Ĕ̈itim Fakültesi Dergisi, 18(18).

11. Çoban, A. (2015). Öğretmen eğitiminde mikro-öğretim ve farklı yaklaşımlar. Elektronik Sosyal Bilimler Dergisi, 14(53), 219-231.

12. Ekşi, G. (2012). Implementing an observation and feedback form for more effective feedback in microteaching. Education \& Science/Egitim ve Bilim, 37(164).

13. Friebel, A. C., Kallenbach, W. W. (1969). Effects of videotape feedback and microteaching as developed in the field test of minicourse 1 with student teachers. Paper presented at the California Educational Research Association meeting, Los Angeles, California, March 15, 1969.

14. Fernández, M. L. (2010). Investigating how and what prospective teachers learn through microteaching lesson study. Teaching and Teacher Education, 26(2), 351-362. doi:10.1016/j.tate.2009.09.012

15. Görgen, İ. (2003). Mikroöğretim uygulamasının öğretmen adaylarının sınıfta ders anlatımına ilişkin görüşleri üzerine etkisi. Hacettepe Üniversitesi Ĕ̈itim Fakültesi Dergisi, 24(24).

16. Gürbüzoğlu Yalmacı, S. \& Aydın, S. (2014) (2014). Öğretmen adaylarının mikro öğretim uygulamalarına yönelik görüşleri. Turkish Journal of Education, 3.

17. Güven, S., Kahveci, Ö., Öztürk, Y., \& Akın, Ö. (2016). Türkiye'de mikro öğretim uygulamalarıyla ilgili yapılan çalışmaların içerik analizi. The Journal of International Lingual Social and Educational Sciences, 2(1), 19-34.

18. Karadağ, R., \& Akkaya, A. (2013). İlk okuma yazma öğretimi dersinde mikro öğretim uygulamalarına ilişkin öğretmen adaylarının görüşleri. Ahi Evran Üniversitesi Kırşehir Eğitim Fakültesi Dergisi, 14(2).

19. Karadeniz, Ş. (n. d.). [Blog post]. Retrieved 2017, February from: www.sirinkaradeniz.com/dersler/mikroogretim_degerlendirme.doc

20. Kartal, T., Ozturk, N., \& Ekici, G. (2012). Developing pedagogical content knowledge in preservice science teachers through microteaching lesson study. Procedia-Social and Behavioral Sciences, 46, 2753-2758. 
21. Kuran, K. (2009). Mikro öğretimin öğretmenlik meslek bilgi ve becerilerinin kazanılmasına etkisi. Mustafa Kemal Üniversitesi Sosyal Bilimler Enstitüsü Dergisi, 6(11).

22. Küçükoğlu, A., Köse, E., Taşgın, A., Yılmaz, B. Y., \& Karademir, Ş. (2012). Mikro öğretim uygulamasının öğretim becerilerine etkisine iliş̧in öğretmen adayı görüşleri. Eğitim Bilimleri Araştırmaları Dergisi, 2(2), 1932.

23. Pauline, R. F. (1993). Microteaching: An integral part of a science methods class. Journal of Science Teacher Education, 4(1), 9-17.

24. Peker, M. (2009). The use of expanded microteaching for reducing pre-service teachers teaching anxiety about mathematics. Scientific Research and Essays, 4(9), 872-880.

25. Ralph, E. G. (2014). The effectiveness of microteaching: five years' findings. International Journal of Humanities Social Sciences and Education, 1(7), 17-28.

26. Swanborn, P. (2010). Case Study Research: What, Why and How? London: SAGE Publications Inc.

27. Şahinkayası, H. (2012, April 17). Mikroöğretim akran değerlendirme formu. [Blog post]. Retrieved from http://hsahinkayasi.blogspot.com/2012/04/ozel-ogretim-yontemleri-ii.html 